\title{
Teachers' Discourses on Teaching Students of Elementary School English Literacy Development in Ontario
}

\section{Katherine Brubacher}

This article explores teachers' discourses on teaching English Literacy Development (ELD) students in mainstream elementary school classrooms through an examination of their philosophies of teaching and reflections on literacy. The findings are based on empirical qualitative data collected from interviews with two English-as-a-second language (ESL)/ELD teachers in two school boards in Ontario. Both participants discussed the importance of developing awareness of and including in classes students' learning and language experiences from outside the formal education system. Challenges perceived in the school communities included the structure of schooling, the demands of the curriculum, the incorporation of students' unwritten first languages, and negative views of ELD students.

Cet article se penche sur la philosophie d'enseignement et les réflexions sur la littératie telles qu'elles découlent des discours d'enseignants évoquant l'enseignement, dans des salles de classe régulières à l'élémentaire, à des élèves en perfectionnement de l'anglais. Les résultats reposent sur des données empiriques qualitatives tirées d'entrevues auprès de deux enseignants en anglais langue seconde et en perfectionnement de l'anglais dans deux conseils scolaires en Ontario. Les deux participants ont discuté de l'importance de faire connaitre les expériences liées à la langue et à l'apprentissage que vivent les élèves à l'extérieur du système d'éducation formel et de les intégrer aux cours. Parmi les défis au sein des communautés scolaires, on a évoqué la structure de la formation scolaire, les exigences des programmes d'études, la prise en compte des langues maternelles non-écrites des élèves et les perceptions négatives des élèves en perfectionnement de l'anglais.

Students arrive in Ontario elementary schools speaking a variety of languages and with diverse experiences with formal schooling. All students who are in the process of learning English are designated as English Language Learners (ELLs) in the Ontario education system (Ontario Ministry of Education, 2007). Some of these children will have experienced success with consistent schooling in either their first language (L1) or in English-medium schools in their home countries, whereas others will have had only limited or interrupted access to formal schooling. This second group of Ontario students is supported under the English Literacy Development (ELD) program. Hamayan (1994) defines the ELD student as "likely to come from one of the 
following environments: isolated rural communities with one-room schools, refugee camps, war-torn countries, and families with persistent migration patterns" (p. 281). The Ontario Ministry of Education (2008) states, "very little Canadian research exists about a small subgroup of English language learners (ELLs) with limited prior schooling, yet these students are in Canadian classrooms and will continue to arrive on an ongoing basis" (p. 3). The purpose of this article is to explore two teachers' discourses used to describe ELD students coming from a diverse range of linguistic, cultural, and educational backgrounds.

Many terms have been used to describe the ELD student. In general, clear definitions and terms for ELD students tend to be lacking (Brown, Miller, \& Mitchell, 2006; DeCapua, Smathers, \& Tang, 2009; Freeman \& Freeman, 2001; Mace-Matluck, Alexander-Kasparik, \& Queen, 1998). Terms such as nonliterate, low-literacy backgrounds, and lower than-expected levels of literacy in both their native language and second language have been used to describe ELD students (Hamayan, 1994). Freeman and Freeman state that "they have been labelled as overage, preliterate, or low literacy" (p. 203). Another term, used by researchers DeCapua et al., is students with limited or interrupted formal education (SLIFE). However, these terms continue to label students in terms of what they are missing or lacking rather than of what they are in the process of learning or developing. In this study, I refer to this group as ELD students: students who are in the process of developing their literacy skills in the English language.

Researchers (Carrasquillo \& Rodríguez, 2002; Cummins, 2001; Gérin-Lajoie, 2008a) find that there is little training for inclusion, diversity, and language-teaching in teachers' preservice programs. Teachers are often unprepared to deal with teaching new immigrants, let alone those arriving in the classroom with little prior schooling or exposure to reading and writing in their first language. In Australia, Dooley (2009) reported that a number of ESL teachers had started to create literacy classes for ELD students based on the view that the level of instruction in the ESL classes did not address basic literacy skills and on the assumption that students had strong literacy skills in their first languages. Brown et al. (2006) conducted a study on secondary-level ELD students in Australia who were over the age of 16, predominantly from the Sudan, and who had experienced as few as three years of schooling. They reported that ELD students perceived the following changes as necessary to their academic success.

- more teachers

- more help with English in mainstream subjects

- peer support with "someone from [their] own culture"

- time to "learn more before [they] come to high school." (p.11)

Only a limited number of related studies have been completed in Ontario; these have focused on refugee students' experiences with education in gen- 
eral, and not all included ELD students. Kaprielian-Churchill and Churchill (1994) completed an in-depth analysis of the experiences of refugee students in Ontario, some of whom had limited prior schooling or were described as coming from poor rural areas. They found that it was difficult to find consistent census data on the number of refugees living in Ontario because of the high transiency rate. Some of the students in their study criticized teachers for their uncaring attitudes and racial prejudice and described how classmates ridiculed the refugees because of their food, clothes, behavior, or skin color. Another study (Yau \& Toronto Board of Education, 1995) found that refugee students made up almost 10\% (7\% at elementary and 13\% at secondary) of all students in Toronto schools. In that study, refugee students described feeling satisfied with their schools; however, they did not feel socially accepted in the mainstream setting; there they experienced alienation, discrimination, and sometimes rejection and felt targeted by bullies and racists.

Since becoming an ESL/ELD teacher in Ontario elementary schools, I have been interested in understanding teachers' discourses on teaching ELD students and their perceptions of new immigrants, especially ELD students. How teachers define their roles as educators can constrain ELLs' experiences in the classroom (English, 2009). Many ELD students have their first consistent experiences with teachers in Ontario schools. ELD students' previous classroom experiences, especially if they have been inconsistent or interrupted, may have already negatively affected how they view themselves as learners. Moreover, ELD students must grapple not only with literacy and schooling, but also with issues related to race, language, culture, and class. In this study, I examine the discourses of two Ontario elementary schoolteachers who have worked extensively with ELD students as ESL/ELD support teachers in integrated mainstream classroom settings.

\section{Theoretical Foundations}

In the field of qualitative research, my study takes a critical perspective that examines teachers' discourses on teaching ELD students. I use the term discourse to describe teachers' beliefs, attitudes, and/or ideologies as they pertain to diversity and teaching. For the purposes of this article, discourses are understood as how institutions such as schools define the "truth" and how this definition of truth influences the choices that people make in that institution (Gérin-Lajoie, 2008b). As the experiences of ELD students are complex and understudied, for my framework I address philosophies of teaching, multiliteracies, and Bourdieusian language theory gain a better understanding of the macro-level forces informing the choices that teachers make in the classroom.

Philosophies of teaching is a term that is common in the discourses of educators when they reflect on their roles and their thoughts about schooling in general. Thus questioning and reflections related to philosophies of teaching were familiar to the teachers participating in this study. In general, a philos- 
ophy of teaching is a teacher's vision of the purpose and process of education; however, at its essence, it reflects teachers' values and beliefs. Donnelly (2009) suggests "using a teaching philosophy to provide evidence of a teacher's sincerely-held beliefs, codify pedagogical thinking at a particular time, examine teaching practices, and [monitor] one's development as a teacher" (p. 39). By examining teachers' philosophies of teaching, I hoped to understand better the discourses that influenced their views of ELD students.

Pedagogy is an important aspect of any philosophy of teaching. In this article I explore literacy pedagogy through a multiliteracies lens that focuses on cultural and linguistic diversity. The New London Group (1996), which coined the term multiliteracies, asked that an understanding of literacy be extended to include "the context of our culturally and linguistically diverse and increasingly globalized societies" as well as to account for "the burgeoning variety of text forms associated with information and multimedia technology" (p. 61). In my study, multiliteracies are understood to be a form of transformed practice that asks teachers to incorporate the cultural and linguistic experiences of students and to examine critically the pervasive discourses that influence them.

How language is valued situates ELLs in a hierarchy of official languages. Bourdieu (2001) addresses the power of language in how it is defined and positioned. When a language is defined as a dialect or patois, it loses linguistic capital: it is not a legitimate language. Bourdieu explains that when dialects became devalued and a new hierarchy of linguistic capital developed, a division occurred between the language used in school and the language used in the home. This led to a devaluation of different ways of speaking, and this is the situation that exists in schools today. The current study also examines teachers' discourses on language through a Bourdieusian lens. In these critical terms, the project investigates teachers' discourses on teaching ELD students.

\section{Methodology}

In this article I draw on qualitative research, a "situated activity that locates the observer in the world. It consists of a set of interpretive, material practices that make the world visible" (Denzin \& Lincoln, 2005, p. 3). The research was designed to answer the following questions.

- How do teachers' discourses about schooling and teaching influence the experiences of ELD students in mainstream classrooms?

- What role do discourses on language, literacy, and diversity play in shaping teachers' pedagogies for ELD students?

To answer these questions, I analyzed the discourses of two teachers who participated in semi-structured interviews. The participants were chosen based on their previous experiences as ESL/ELD teachers in Ontario elementary schools. I used professional contacts to recruit teachers with varied experiences and identities. The semi-structured interviews focused on 
participants' thoughts on teaching (including what they perceived as the purpose of education, teaching, and schooling), on diversity, and on ELD students and literacy programming for ELD students specifically. Cousin (2009) asserts that "semi-structured interviews allow researchers to develop indepth accounts of experiences and perceptions with individuals" (p. 71). Once the interviews had been conducted, I fully transcribed the resulting tapes. I used a mixed-model coding system with preselected codes and emerging codes. Preselected codes, which are influenced by Cummins' (2000, 2001, 2009) research on coercive versus transformative teaching, as well as by the literature on multiliteracies and philosophy of teaching, included: prior knowledge, home languages, community involvement, literacy engagement, assessment tools, critical framing, and diversity. Emerging codes included teaching experience, student and teacher relationships, description of ELD students, vernacular English, lack of a written first language, peer support, and forms of schooling.

\section{Participant No. 1: Melissa}

Melissa had been teaching for 17 years in many countries, including Mexico, Korea, Bulgaria, England, Germany, and Canada. For the previous five years, she had been an ESL/ELD teacher in Ontario. She said that except for her four years in Newfoundland, her entire career had been with second-language learners. At the time of the interview, she was a qualified ESL teacher completing her master's degree in second-language reading and writing. The school in which she had been working for the previous five years had a large population of Low German-speaking Mennonites, many of whom were ELD students and some of whom were immigrants from Mexico. Melissa said that the school had such a high population of ELLs that teachers had first to create modified lesson plans and then to modify these for the two or three mainstream students in their classrooms in order to meet grade-level curriculum expectations.

\section{Melissa's Thoughts on Education and Teaching}

Inclusion and tolerance of diverse belief systems and cultures were central to Melissa's philosophy of teaching. She was critical of how her ELD students, Low German-speakers that Melissa labeled Old Colony Mennonites or Plaudietsh speakers, were treated by the larger community and even by other groups of Mennonites in the school. She found that many teachers and other community members did not believe that Old Colony Mennonites valued education, as they missed years of schooling and often did not attend school beyond grade 8 . Conflicts arose at times between what the families wanted and the rules and expectations of society. She described some of the families as subsisting and doing migrant work with their children for part of the year. Melissa believed that it was important to be patient with Old 
Colony Mennonite children and not to force them to attend school more regularly. As she explained, they might be the first in their family to learn to read, but the hope was that in future, they would teach their own children to read and write. Melissa said that many members of her staff did not know what it was like to be an outsider, to live in an unfamiliar culture. However, the teachers in her school were somewhat understanding of the irregular attendance of the students and understood the issues of poverty faced by the students. For example, the school implemented a health and dental program because the students did not have consistent access to these services.

Including the parents of ELD students in their children's education was of particular importance to Melissa. She found that some of the Canadianborn, Pennsylvania Dutch-speaking fathers (another group of Mennonites in her school, who tended to be established landowners) came to parents' council meetings; however, none of the women and none of the Old Colony Mennonites, largely immigrant and ELD, attended. Some of the Pennsylvania Dutch mothers came to school at lunch time to lead a choir group, but the Old Colony ELD students were not included in this activity. This concerned Melissa, so she developed an evening program in which Old Colony parents learned strategies to help their children to read at home:

The first time I did it, I focused on helping them understand how important it is to develop Dietsch, so that when kids bring home books, they don't have to read the books with their kids because most of them can't read anyway, but they can just talk about it. Tell the story using the pictures and using Dietsch. I had seven moms, which equalled 19 children for that program.

Only Old Colony mothers were invited to the evening program; the school also offered a sewing program to try to engage these mothers. All parents, however, were invited to monthly assemblies and picnics, and Melissa said that there was a fairly good turnout on parents' night. Many of the students' families were large, so babysitting was an issue. Transportation was also a concern, but many of the families car-pooled. Some of the teachers and the school administrator attended a local community church group meeting every Wednesday in order to encourage the parents to become more connected to the school.

\section{Melissa's ELD Students and Their Programming}

Melissa had extensive knowledge of the students' prior learning experiences. She discussed some students' schooling experiences in Mexico at parochial schools before they had come to Canada. She described some of the students' schools in Mexico as being similar to 1950s rural schools where students sat in rows and wrote on slate chalkboards. She said that before immigrating to Canada, some of the Old Colony Mennonite students had attended schools 
where classes were taught in High German, the language of their churches, but not a language they understood. They learned to decode and memorize in German, but often the students' comprehension level was much lower than their decoding skills.

Because many of the ELD students in Melissa's elementary school had extensive prior experience of singing in choirs in their places of worship outside school, the school's music teacher had them perform the entire Handel's Messiah. Also, as many of the ELD students and other ELLs in the school had extensive knowledge of farms and building barns, her school participated in the Canada Skills construction competition where, she reported, they did well.

Melissa believed that it was important not to generalize about the Old Colony culture. Whereas some students in Mexico had no electricity and used horses for transportation, other old Colony students there had been exposed to television and cell phones. She said that there was also some diversity in the clothing worn by the group:

Even within our building, in the same Old Colony Community, we go from kids that wear jeans, to kids that everybody in the family wears the same clothes. It's all homemade by Mom. It's all black trousers with suspenders and shirts, right? And it's the same. The same colors, the same clothes ... [but] there's quite a range. Even within that community in our building.

However, conflicts did arise between students' and teachers' expectations. Melissa found that students would sometimes become confused over the more relaxed styles of teaching in Canada. She explained that some students did not know how to relate to an authority figure who was not remote. In some situations, they appeared reluctant to talk to or look at her; however, when she joked with students or teased them, they started touching her clothes as if she were a close friend. Melissa said that there was no neutral, in-between relationship and that some students' behaviors were perceived as disrespectful by some of the teachers in the school.

As the ESL/ELD teacher, Melissa saw it as her mission to promote students' first languages around the school. The two main languages in the school, Plautdietsch (spoken by the ELD students) and Pennsylvania Dutch (spoken by other ELLs) were not written languages, so incorporating them into lessons was sometimes a struggle. She purchased a dictionary that had recently been published in Plautdietsch, so that it could be used as an educational resource. Trying to incorporate students' first languages into signs around the school was also important. Every morning the Lord's Prayer was read to the school in Dietsch, Pennsylvania Dutch, English, and Spanish. She enjoyed watching the students' reactions to hearing their languages spoken. 
Melissa considered oral language an important component of students' literacy programming, because as she stated, "If they do not know how to talk in English, how can they write English?" However, she found it challenging to teach critical literacy and critical thinking skills to this group of students. One year, she tried to have her students think critically about gender roles and found that the students became frustrated with the topic and in one case angry with her. Sometimes technology was more successfully incorporated into lessons. Students used computers and followed a strict code of conduct; audiovisual technology was more limited, however, as many students were not allowed to watch television because of their families' religious beliefs.

\section{Participant No. 2: Denise}

During Denise's first five years of teaching, she worked in a private girls' school with a social justice, anti-racist, feminist mandate. While at this school, she taught social studies, history, geography, science, and civics to students from grades 6 to 10 . However, she wanted to work in the public system, and eventually she was hired as an ESL/ELD teacher for grades 6-8; she was working there when she was interviewed for this study. During her first two years in the public school, all ELLs who were newcomers were placed in a separate class where Denise taught more than 30 students for half a day. For four years prior to this study, she had been supporting all ELLs, including ELD students, in mainstream classrooms. She worked with a range of ELD students, approximately three per year, from Jamaica, Afghanistan, and Pakistan. She was a qualified ESL/ELD teacher and attended many of the professional development workshops that her school board offered and described herself as a social activist.

\section{Denise's Thoughts on Education and Teaching}

Denise viewed education as a basic right and responsibility for all students. She believed this, she said, because the power of the written word is enormous: "And I think that when we don't have a strong literate base, people are more easily subject to their rights being tampered with and their overall human rights, but also ... individual rights." Denise provided the example of a mother who does not understand the medication that her doctor has prescribed. Basic literacy skills are crucial, as is exposing students to a wide variety of literature and experiences. She believed that teachers must be in tune with their students as whole people and create comfortable, low-risk environments where students feel safe taking academic risks.

Denise incorporated students' prior knowledge into her literacy practices. She explained that all her ELLs, whether they were from South Asia or the Caribbean, came from colonial backgrounds. She worked with a classroom teacher to create a unit that focused on the Chinese railway workers and had her ELLs read a picture book, Ghost Train by Paul Yee. She found this to be a 
much more valuable way to approach diversity than the shows, festivals, and food fairs that her school principal encouraged her to organize. She referred to the latter approach as "Public Relations (PR) diversity," in that it was standardized and did not include the cultures of all the students in her school. Denise had started an anti-bullying club at lunchtime at her school. There she promoted the use of students' first languages, especially for IndoCaribbean students who, she stated, viewed their own first language as "broken English." She taught them about the rich history of their languages and culture. Moreover, Denise discussed with her ELD students their struggles with their experiences in Ontario schools. She related a moment in her classroom when one of her new comer ELD students from Jamaica described having been mugged over the weekend in Ontario.

When I asked him if this kind of thing would have happened in Jamaica where he grew up, he said, "No way," because everybody there knew his father. Here his father is just another face. Nobody knows who he is. Back home his father was highly respected in the community, so he had a huge sense of social security, whereas here it's all stripped. That's how he feels.

In this case, Denise described the student's experience of Ontario as a place of violence.

Denise described practices in her school that promoted community involvement. She discussed how she took time to connect with parents through a phone calls or meetings when they were newcomers to Canada. The school also had a settlement worker who was a valuable resource for newcomers. The settlement worker telephoned parents and invited them to the school for information sessions on job-hunting and other topics. Moreover, the school had a special welcome program for newcomers, which provided new families with a tour of the building and the opportunity to learn the school's procedures. Denise believed that it was important to invite the parents of ELLs into the school and to have sessions during which teachers answered frequently asked questions.

\section{Denise's ELD Students and Their Programming}

Denise was concerned about how her ELD students were perceived and treated by other students and by members of the staff. She found that her ELD students progressed much better in some classes than in others and that this had to do with how teachers interacted with them: whether they kicked them out of class or tried to get to know them better. Denise reflected on a negative interaction between staff members and an ELD student:

I think it's the fact that [the student's] not a self-starter. I think it bothers [the teachers] that he's got his chin on the desk and he's not doing anything academically until somebody comes to help him, 
and they see that as this kind of learned helplessness thing. But then he also picks up on that vibe and then, I think he resists it, but he hates them for seeing through him ... seeing their perspective through him. I don't know if that makes sense, but kind of seeing what they think, but not understanding him. Never having a conversation with him before making these judgments. Looking at him and sort of denying his experience.

She recalled a conversation with a classroom teacher who was upset because her Guyanese ELD student could not read the word Confederation, which the teacher thought was easy because it was spelled phonetically. Denise also worried about how other students in the school treated ELD students and newcomers in general. While on supervision duty on the playground, she saw that ELD students and other newcomers were often bullied and excluded by students, even by students who looked like them.

With ELD students, Denise found that the best learning happened when she worked with them in small groups. She had a newcomer ESL class of 30 students when she first started teaching at that school; consequently, she found it difficult to create appropriate programming for the ELD students. She found that their literacy needs were much different from those of the other ELLs. When supporting her ELD students in small groups, on the other hand, she could scaffold the students' learning and guide them in developing rich understandings. She liked to use graphic organizers and technology such as a talking word-processor to support her students' learning. She said that $90 \%$ of the time the ELD students in the school received oral assessments.

Denise was knowledgeable about critical literacy and tried to use it in her program, but she found this difficult because of other pressures exerted by mainstream teachers. She had one ELD student tell her his story, which she typed into a talking word-processor for him. The student then listened to his own story, which had become a written text.

And he sat there and he watched and-first of all the amount of text that was there-he couldn't even believe it. He couldn't even believe that those were all his words, so that alone was very empowering, but then to see every word being read and to hear somebody else reading it. At one point ... he was sitting there with his eyes closed and he was almost in tears because his story was being mirrored and it was being validated and so on. So in terms of the critical literacy to me was an example of that because he was reflecting critically at his environment and something that he actually experiences on an everyday level. But he's chosen to problematize it and not make this normal for him and that's to me a sign of him looking at things in a critical perspective. 
Here Denise described a student who was beginning to learn that he could construct written texts and control how his story was written.

\section{Analysis of Participants' Philosophies of Teaching}

When discussing their philosophies of teaching, Denise and Melissa emphasized the importance of having a deeper understanding of their students. Researchers such as Cummins (2001) find that relationships between students and teachers are more important than any approach to teaching. Similarly, Gersten's (1999) research suggests that highly effective teachers find ways to engage with their students both on academic and interpersonal levels. Denise and Melissa discussed taking time to learn about their ELD students' strengths and personal interests and attempting to incorporate these interests into the learning process. Sticking rigidly to a curriculum that did not reflect the prior experiences of ELD students can further work toward disengaging them from school, as Melissa explained.

Well, one of the big issues that we have is that our kids have very little background knowledge about a lot of the curriculum topics. So we spend a lot of time just trying to teach them about things they've never heard of.

Much of the curriculum did not connect to ELD students' personal lives. In these circumstances, Melissa was required to provide in class the knowledge that the curriculum assumed was possessed by all students. By relating to students and finding out about their personal interests and experiences, however, teachers can create programming that is relevant to them. Melissa's and Denise's discourses revealed a view of their roles as being not only about imparting academic knowledge, but also about relating to their students.

Lack of understanding of students' prior experiences may hinder teachers' abilities to create authentic learning experiences with their ELD students. Cummins et al. (2005) define prior knowledge as the totality of experiences that have shaped students' learning (and not just experiences in formal schools); this is essential to students' academic development. Teachers must learn about students' cultures, backgrounds, and families (Musetti, Salas, \& Perez, 2009) or risk alienating learners in the classroom. Melissa's school attempted to incorporate students' prior knowledge by entering them in building competitions and by having the school choir sing Handel's Messiah, which was familiar to them. In this way, the discourse in Melissa's school was one of validating and including what students had learned outside the classroom.

Teachers' discourses on race, ethnicity, or even culture can affect all ELLs' experiences with education, as well as their relationships with teachers. Denise was critical of the "shows, festivals, and food fairs" approach to diversity and instead found time to integrate diversity across the curriculum. Her discourse on diversity had a critical lens that asked students to examine 
examples of oppression and racism in Canadian history and not just celebratory forms of multiculturalism. Melissa, on the other hand, described the discourse on Old Colony Mennonite in her school community as being negative, essentialist, and exclusionary. No Old Colony Mennonite parents were on the parent council, and their children were not included in the lunchtime choir organized by other members of the community. The Old Colony Mennonite community was a group whose cultural values were often essentialized as conservative, male-dominated, and fundamentalist (Gingrich, 2006). Melissa recalled that some of the Mennonite mothers who came for parent interviews asked questions; other mothers just sat there and did not look the teacher in the eye while the fathers did all the talking. Here she observed actions that were contrary to her own personal values in that some of the women did not speak or make eye contact with her. However, she was careful not to essentialize all her students' families as having these same cultural or religious values, as she saw differences even in the Old Colony Mennonite community. Labelling Old Colony Mennonites is, moreover, a social construction. Li (1999) sees ethnicity as constructed on social relationships. To understand ethnicities as cohesive, unified groups is fraught with contradictions. However, it is inherently assumed that they are a group that shares the same experiences, and in this case, values. Both Denise and Melissa were critical of the discourses on diversity in their schools and to varying degrees attempted to challenge established ways of thinking about race and culture.

Another important aspect of teachers' philosophies of teaching is their understanding of schooling and the purpose and structure of schooling. First, learning can happen in many ways, both in and out of school. For ELD students specifically, education needs to be understood as something that does not happen only in school. Researchers such as Farrell (2008) outline the norms of formal schooling, which include a formal curriculum, same-age groups, and a building with desks, among others. He says that a standard set of practices for formal schooling was created in the West and spread throughout the world in the forms of colonization and modernization. However, not all these characteristics of formal schooling may respond to the needs of ELD students. For example, Dooley (2009), an Australian researcher, found that parents, students, and educators all agreed that aged-based placement was a source of problems. It did not enable students to develop their literacy skills to the level necessary for participation in critical thinking and intensive academic areas. Denise observed what had happened in her school when two ELD students were placed in mainstream classrooms in a formal school setting.

They can't, they don't know how to find their way to learn, so in both cases the boys have ... responded by, by shutting down. One has become more behavioral — the other has become completely withdrawn, and $80 \%$ of the day he's got his head on his desk. 
Melissa also discussed the effect of forcing ELD students into the structure of formal schooling.

What they want from school is not what we are trying to give them ... I can see this struggle in, in my building trying to make them fit into ... school; whereas, they are trying ... to figure out how to do school.... What do I do in this building and how do I even make sense of what goes on here? How's this going to be of any use to me whatsoever?

Students' struggles to understand the purpose of schooling and to have positive relationships with their teachers reflect a conflict between teachers' discourses on teaching and ELD students' experiences with schooling. Similarly, Dachyshyn's (2008) study in an Edmonton community found that refugee parents often wanted more moral education to be provided in schools and were worried about the negative behaviors that their children were learning. Both Denise and Melissa observed tension between what ELD students wanted from schooling and what they were getting. ELD students were in the process of adjustment, from being learners outside the classroom-in the home and in the community, through nonformal education and informal learning structures (Rogers, 2005) - to being students learning in a formal school setting. Both participants' discourses revealed views on how formal schooling could negatively affect ELD students.

\section{Language and Literacy in the Classroom}

In an attempt to create relevant programming for her ELD students, Denise used phonics strategies.

Repeating those basic strategies of decoding, you know, reviewing the alphabet because some of our students still don't recognize each letter or they mix up letters, reverse letters and, so, sound letter recognition is a big part and sometimes it takes an entire year to mainly get that.

Denise found that teaching basic literacy instruction was important. Dooley's (2009) research into the experiences of ELD students in Australian schools found that teachers faced the difficult challenge of combining tasks that were conceptually deep and critical while also building students' basic literacy skills. However, as Dozier, Johnston, and Rogers (2007) assert, teachers must not "view some children as constitutionally beyond the reach of their strategic practice" (p. 12). If teachers view ELD students as incapable of critical framing and deeper reading comprehension activities, they will continually focus on simple reading and writing tasks. Researchers (Freeman \& Freeman, 1998; Mace-Matluck et al., 1998) have found that oral language is important 
to the development of successful literacy programs for ELD students. If students have not learned to read and write, they will rely on their oral language as well as the visual components of text in their daily lives. As Denise stated, $90 \%$ of her schools' assessments for ELD students were done orally. She asserted that students felt more confident when allowed to work in small groups discussing ideas with their peers, and that they became engaged in conversations that focused on their prior knowledge and experiences. Thus Denise's discourse on literacy encompassed the importance of both building basic literacy skills and scaffolding learning so that students had the opportunity to critique constructively what they had learned.

Some ELD students may have had no prior experience with written text, but most will have had experience in decoding the visual aspects of texts. Norton and Vanderheyden (2004) stress the importance of graphics in any literacy program. Similarly, Freeman and Freeman (1998) suggest that teachers use graphic texts that include photographs or illustrations. Denise observed the prior experiences that her ELD students brought to reading the visual components of texts: "All their life they've been used to reading things without words, reading visuals, reading subtleties, and so they're very trained in that." She saw strengths in her ELD students' literacy abilities: understanding how the visual components of text created meaning. Similarly, Melissa highlighted the strengths of the mothers of her ELD students, who could participate in their children's education by using pictures and their first language to tell stories. As the New London Group (1996) states, a multiliteracies pedagogy "focuses on modes of representation much broader than language alone" (p. 64). Both Denise's and Melissa's discourses on literacy revealed a perspective that recognized the strengths that ELD students and their families brought to learning through the reading of the visual aspect of texts. Although they did not have a written language, they did have an understanding of literacy.

Both Denise and Melissa found unique and inventive ways to bring students' first languages into the school. An additional struggle for Denise and Melissa was finding how to incorporate home languages that had no written form. Both these teachers worked with students who spoke non-standard forms of languages: among them, Indo-Caribbean languages such as JVE, and two Mennonite languages, Plautdietsch and Pennsylvania Dutch. Melissa described Plautdietsch as a Dutch language and said, "Neither one of [the Mennonite] languages are written in a standardized way." Bourdieu (2001) explains that the existence of dominant or official languages suppresses the languages of the less powerful, marginalizing their cultures and experiences. For example, Cross (2003) found that male students in a middle school in Jamaica defined their JVE as bad and the standardized English used in school as good, even though JVE was the language they used on the playground. Like Bourdieu, Dicker (2003) found that language can determine 
who is part of the in-group, and it works to marginalize those who do not speak the language of those in power. To combat this devaluation, Denise discussed incorporating and even promoting students' home languages. She took the time to explain the history of Indo-Caribbean languages and encouraged her students to see their languages as amazing new creations and not as broken English. She attempted to create change in her school by challenging the students to question how their own languages had been defined and excluded.

If "cultural and linguistic diversity is a classroom resource" (New London Group, 1996, p. 69), how can languages that are not written be incorporated into students' literacy programs? Bryan (1997) proposed that vernacular languages be used as a learning tool just like any other language. Learning the new or standardized language needs to be thought of as second-languagelearning. Despite the difficulties of incorporating an unwritten language into a literacy program, especially a writing program, Melissa attempted to find creative and original ways to make her ELD students' languages a part of their literacy programming: such as posting students' languages around the school and having students learn to write for the first time in their L1. She strove to redesign the discourse on language in her school. The New London Group (1996) states, "literacy educators and students must see themselves as active participants in social change" (p. 64). In this study, the ESL/ELD specialist teachers moved beyond using students' L1 for peer translation and considered how they could create change in their schools by making the ELD students' L1 an essential part of their schooling experiences. Similarly, teachers can work toward transforming their students' learning by critically framing the rich history of their spoken languages and by challenging students' negative perceptions of their home languages.

\section{Conclusions}

This work explored the underlying discourses that influenced two Ontario ESL/ELD teachers' philosophies of teaching and reflections on literacy and diversity as they pertained to teaching ELD students. Both Denise and Melissa went out of their way to find out how to connect with their ELD students outside the classroom and on a personal level. This gave them both a wealth of knowledge of students' prior experiences. They then incorporated these prior experiences into classroom discussions, students' assignments, and instructional strategies. The learning that students had experienced outside the confines of a formal school was thus valued and deemed an important aspect of their programming. As illustrated above, both Denise's and Melissa's discourses revealed a definition of education that included the totality of a student's experiences, not just what was learned in the classroom.

However, by forcing students to attend formal school and by not adapting the structure of schooling to meet the specific needs of ELD students, a school cannot inherently reflect the students' prior experiences. Participation in a 
mainstream classroom in a formal school setting for five hours a day, five days a week, is not reflective of ELD students' prior experiences. Moreover, ELD students' prior experiences need to become a part of all classroom teachers' pedagogy and not just that of ESL/ELD teachers. The deeper structure of schooling needs to be more closely examined in order to create a transformative pedagogy that is inclusive of ELD students' experiences.

The challenge of using students' L1s, which may not be written languages, was discussed by the participants. Both ESL/ELD teachers managed to find creative and unique ways to incorporate students' L1 into their classes; these practices were not necessarily adopted by the school community at large, however. Melissa and Denise both struggled to meet the expectations of the school curriculum and to support their ELD students' learning in mainstream classroom settings. They used oral language to engage ELD students in class discussions and group work. This allowed for the possibility of having students critically frame the discourses that influenced their lives, although neither teacher discussed using at length any form of critical thinking with their ELD students.

ELD students arrive in elementary schools in Canada with vast and varying prior learning experiences, thereby creating possibilities for responsive, innovative programming. Flexible schooling and programming can enhance a dynamic and inclusive school atmosphere. Teachers have the opportunity to move beyond traditional ideas of the formal school, literacy, and the normalization of the white, Canadian-born, English-speaking student to a truly inclusive style of education that embraces diversity and uses it as a vehicle for innovation and change.

\section{The Author}

Katherine Brubacher (MA, OISE/University of Toronto, 2011) is an elementary schoolteacher with 10 years of teaching experience, much of which has been spent teaching ELLs. As well as teaching in Ontario, she has taught in London (UK), Prague, and Laos.

\section{References}

Bourdieu, P. (2001). The production and reproduction of legitimate language. In J. Thompson (Ed.), Language and symbolic power (pp. 43-65). Cambridge, MA: Harvard University Press. Brown, J., Miller, J., \& Mitchell, J. (2006). Interrupted schooling and the acquisition of literacy: Experiences of Sudanese refugees in Victorian secondary schools. Australian Journal of Language and Literacy, 29(2), 150-162.

Bryan, B. (1997). Investigating language in a Jamaican primary school: Perceptions and findings of a group of primary school teachers. Changing English, 4(2), 251-258.

Carrasquillo, A., \& Rodríguez, V. (2002). Language minority students in the mainstream classroom. Toronto, ON: Multilingual Matters.

Cousin, G. (2009). Researching learning in higher education: An introduction to contemporary methods and approaches. New York: Routledge.

Cross, B. (2003). "Watch mi eyes": The predicament of visual and scribal literacy choices, as explored with rural Jamaican adolescent boys. Compare, 33(1), 65-82. 
Cummins, J. (2000). Language, power and pedagogy: Bilingual children in the crossfire. Clevedon, UK: Multilingual Matters.

Cummins, J. (2001). Negotiating identities: Education for empowerment in a diverse society (2nd ed.). Covina, CA: California Association for Bilingual Education.

Cummins, J. (2009). Pedagogies of choice: Challenging coercive relations of power in classrooms and communities. International Journal of Bilingual Education and Bilingualism, $12,261-271$.

Cummins, J., Bismilla, V., Chow. P., Cohen, S., Giampapa, F., Leoni, L., Sandhu, P., \& Sastri, P. (2005). Affirming identity in multilingual classrooms. Educational Leadership, 63, 38-43.

Dachyshyn, D.M. (2008). Refugee families with preschool children: Adjustment to life in Canada. In L.D. Adams \& A. Kirova (Eds.), Global migration and education: Schools, children, and families (pp. 251-262). Mahwah, NJ: Erlbaum.

DeCapua, A., Smathers, W., \& Tang, L. F. (2009). Meeting the needs of students with limited or interrupted schooling: A guide for educators. Ann Arbor, MI: University of Michigan Press.

Denzin, N.K., \& Lincoln, Y.S. (2005). Introduction: The discipline and practice of qualitative research. In N.K. Denzin \& Y.S. Lincoln (Eds.), The Sage handbook of qualitative research (3rd ed., pp. 1-32). Thousand Oaks, CA: Sage.

Dicker, S.J. (2003). Languages in America: A pluralist view (2nd ed.). Toronto, ON: Multilingual Matters.

Donnelly, R. (2009). Supporting teacher education through a combined model of philosophical, collaborative and experiential learning. Journal of the Scholarship of Teaching and Learning, 9(1), 35-63.

Dooley, K.T. (2009). Re-thinking pedagogy for middle school students with little, no or severely interrupted schooling. English Teaching: Practice and Critique, 8(1), 5-22.

Dozier, C., Johnston, P., \& Rogers, R. (2007). Critical literacy, critical teaching: Tools for preparing responsive teachers. New York: Teachers College Press.

English, B. (2009). Who is responsible for educating English language learners? Discursive construction of roles and responsibilities in an inquiry community. Language and Education, $23,487-507$.

Farrell, J.P. (2008). Community education in developing countries: The quiet revolution in schooling. In F.M. Connelly (Ed.), The Sage handbook of curriculum and instruction (pp. 369389). Thousand Oaks, CA: Sage.

Freeman, Y.S., \& Freeman, D.E. (1998). ESL/EFL teaching: Principles for success. Portsmouth, NH: Heinemann.

Freeman, Y.S., \& Freeman, D.E. (2001). Keys to success for bilingual students with limited formal schooling. Bilingual Research Journal, 25, 203-213.

Gérin-Lajoie, D. (2008a). What next? Official discourse and school reality. In D. Gérin-Lajoie (Ed.), Educators' discourses on student diversity in Canada: Context, policy, and practice (pp. 183-195). Toronto, ON: Canadian Scholars' Press.

Gérin-Lajoie, D. (2008b). Student diversity and schooling in metropolitan Toronto: A comparative analysis of the discourses of anglophone and francophone school personnel. In D. Gérin-Lajoie (Ed.), Educators' discourses on student diversity in Canada: Context, policy, and practice (pp. 109-132). Toronto, ON: Canadian Scholars' Press.

Gersten, R. (1999). Lost opportunities: Challenges confronting four teachers of Englishlanguage learners. Elementary School Journal, 100(1), 37-56.

Gingrich, L.G. (2006). Contesting social exclusion: An interrogation of its self-imposed expressions. Unpublished doctoral dissertation, University of Toronto.

Hamayan, E.V. (1994). Language development of low-literacy students. In F. Genesee (Ed.), Educating second language children: The whole child, the whole curriculum, the whole community (pp. 278-299). Cambridge, UK: Cambridge University Press. 
Kaprielian-Churchill, I., \& Churchill, S. (1994). The pulse of the world: Refugees in our schools. Toronto, ON: OISE Press.

Li, P.S. (1999). Race and ethnicity. In P.S. Li (Ed.), Race and ethnic relations in Canada (2nd ed., pp. 3-20). Don Mills, ON: Oxford University Press.

Mace-Matluck, B.J., Alexander-Kasparik, R., \& Queen, R.M. (1998). Through the golden door: Educational approaches for immigrant adolescents with limited schooling. Washington, DC: Center for Applied Linguistics.

Musetti, B., Salas, S., \& Perez, T. (2009). Success with ELLs: Working for and with Latino/Latina immigrant newcomers in the English language arts classroom. English Journal, 99(2), 95-97.

New London Group. (1996). A pedagogy of multiliteracies: Designing social futures. Harvard Educational Review, 66, 60-92.

Norton, B., \& Vanderheyden, K. (2004). Comic book culture and second language learners. In B. Norton \& K. Toohey (Eds.), Critical pedagogies and language learning (pp. 201-221). New York: Cambridge University Press.

Ontario Ministry of Education. (2007). English language learners-ESL and ELD programs and services: Policies and procedures for Ontario elementary and secondary schools, kindergarten to grade 12. Toronto, ON: Queen's Printer.

Ontario Ministry of Education. (2008). Supporting English language learners with limited prior schooling: A practical guide for Ontario educators, grades 3 to 12. Toronto, ON: Queen's Printer.

Rogers, A. (2005). Non-formal education: Flexible schooling or participatory education? New York: Springer.

Yau, M., \& Toronto Board of Education. (1995). Refugee students in Toronto schools: An exploratory study. Toronto, ON: Toronto Board of Education. 